\title{
RDRS Bangladesh Seasonal Loan Impact on Rice Production: A Study in Rangpur District
}

\author{
Sharmin Afrin \\ Department of Agribusiness \& Marketing, Sher-e-Bangla Agricultural University, Dhaka, Bangladesh
}

Email address:

sharminafrin9@gmail.com

\section{To cite this article:}

Sharmin Afrin. RDRS Bangladesh Seasonal Loan Impact on Rice Production: A Study in Rangpur District. International Journal of Business and Economics Research. Vol. 5, No. 3, 2016, pp. 38-45. doi: 10.11648/j.ijber.20160503.12

Received: April 11, 2016; Accepted: April 19, 2016; Published: May 4, 2016

\begin{abstract}
Agriculture sector plays an important role in the economic development of Bangladesh. Rice is an important and most cultivated crop because it is an essential ingredient for food consumption. Seasonal loan plays a vital role in agricultural farming. This study examines the impact of seasonal loan on the Rice production in Badarganj Upazila of Rangpur district, Bangladesh. Data were collected from 55 small \& medium scale rural farmers, who were categorized into credit borrower and non-borrower of seasonal-loan based. The results revealed that total cost per acre land of credit user farmers is 34590.24 taka which lower than that of non-credit user farmers is 36801.6 taka. Rice productions of seasonal loan borrowers per acre were 2.89 M.ton. Rice productions of seasonal loan non-borrowers per acre were 2.86 M.ton. Per unit price of Rice is 13925 taka in case of borrower. Per unit price of Rice is 14530 taka in case of non-borrower. Total value of Rice in case of borrowers is 40243.25 taka, but total value of Rice for non-borrower is 41555.8 taka. Net return of SL non- borrower per acre Rice field is 8354.2 taka. Net return of SL borrower per acre Rice field was 9253.01 taka. It was observed from the study that the beneficiaries of seasonal loans in the study area were more productive than the non-beneficiaries. Hence, this study recommends that organization should be provided more facility to the credit borrower for increasing Rice production \& profit.
\end{abstract}

Keywords: Credit Borrower, Seasonal Loan, Production Cost, Marketing Cost, Socio-economic Factors

\section{Introduction}

A large proportion of the population in Bangladesh is rural based and depends on agriculture for a living. Enhanced and stable growth of the agriculture sector is important as it plays a vital role not only in generating purchasing power among the rural population by creating on-farm and off-farm employment opportunities but also through its contribution to price stability. The growing adult population in Bangladesh demand large and rise in agricultural production. Agricultural output is low in developing countries especially in Bangladesh due to small holdings, traditional methods of farming, poor irrigation facilities, low or misuse of modern farm technology etc. This results in small income and no saving or small saving. Therefore, it needs of time that credit agencies come up to help them in applying and undertaking the improved farm practices. Credit is an important instrument that enables farmers to acquire commands over the use of working capital, fixed capital and consumption goods. Credit plays an important role in increasing agricultural productivity. Timely availability of credit enables farmers to purchase the required inputs and machinery for carrying out farm operations. After emergence of green revolution, there have been overtime changes in crop production technology, so credit requirements have increased for both inputs for crop production and farm investment. With the breakthrough of green revolution of agriculture by adopting modern technologies during the mid-seventies, the demand for agricultural credit has increased tremendously. Three main factors that contribute to agricultural growth are increased use of agricultural inputs, technological change and technical efficiency. Seasonal loan appears to be an essential input along with modern technology for higher productivity. Moreover, the Crop production in the new agricultural systems is highly input intensive. Consequently, farmers are unable to accumulate enough capital to buy the costly inputs needed for crop cultivation. Early studies indicated that to sustain and accelerate technological change in agriculture for adopting improved practices, credit is essential (Hossain, 
1986). Similarly Jaim and Rahman (1985) observed that although rich and middle class farmers generate sufficient surplus after maintaining a higher standard of living, they too feel need for credit in certain period, particular seasons. Farmers take loan both from informal and formal sources. Due to excessive formalities followed by the nationalized banks, informal compound interest mohazoni system still remains in the rural agriculture. Credit is also available from informal sources against advanced sale of crops at prices much below the level prevailing in the market during the harvesting period.

The formal or institutional sources of credits are (BKB), (RKUB), Grameen Bank (GB), different Nationalized Commercial Banks, and NGO's such as Palli Karma-Sahayak Foundation (PKSF) etc. Those Banks and NGOs provide loan both in cash and kind for accelerating the crop production. One such RDRS provides credit in cash to farmers for sustaining technological change in agriculture by adopting improves management practices. Recently, the government of Bangladesh has given much emphasis to supply agricultural credit to the farmers for achieving selfsufficiency in food within shortest possible time. For desired level of production, more improved technologies and intensive input use is required. Farmers, particularly in Rangpur area take credit for Crop cultivation. It is assumed that the credit taken for agricultural purposes, i.e. Rice, wheat cultivation is not solely used for the purposes.

\subsection{Brief Description of RDRS Bangladesh}

Established in 1972 to assist with relief and rehabilitation of greater Rangpur-Dinajpur region immediately following the War of Independence of Bangladesh in 1971, the RDRS Bangladesh program evolved into a sectoral then comprehensive effort. Formerly the Bangladesh field program of the Geneva-based Lutheran World Federation/Department for World Service, RDRS Bangladesh became a national development organization in 1997. The rural poor and marginalized achieve meaningful political, social and economic empowerment, quality of life, justice and a sustainable environment through their individual and collective efforts. RDRS Bangladesh works with the rural poor and their organizations in order: to establish and claim their rights as citizens; to build their capacity and confidence to advance their empowerment, and resilience to withstand adversity; and to promote good governance among local institutions and improved access by the marginalized to opportunities, resources and services necessary to fulfill decent lives. RDRS Bangladesh is governed by a Board of Trustees comprising leading actors from the humanitarian sector in Bangladesh. Its programs run by a Management Committee consisted of senior staff members. Regular coordination meetings are held involving management and supervisory staff from across RDRS Bangladesh. RDRS Bangladesh is registered under NGO Affairs Bureau. Its registration number is 003; and registration date is 22 April 1981 with renewal on 17 May 2010. RDRS BANGLADESH is now a major multi sectoral development agency focused on disadvantaged northwest Bangladesh. It provides development opportunities and services to around 1,600,000 landless and marginal families in 18 districts, and work with 375 community-based organizations (Federations) seeking to empower their grassroots members. RDRS BANGLADESH maintains a staffing of over 3,000 , over $90 \%$ of whom are field-based.

\subsection{RDRS Bangladesh Working Area}

RDRS BANGLADESH is unusual is maintaining a concentrated geographic program, focusing on 8 districts and 57 Upazila (sub-districts) mainly in deprived north-west Bangladesh in Rangpur Division, far from the over centralized economic and political powerbase of Dhaka, Chittagong, even Rajshahi. This corner of Bangladesh remains one of its most vulnerable, with regular flooding and riverbank erosion of the Brahmaputra and other rivers dominating life, particularly in the east of the region. The climate is colder and drier than the rest of the country, also causing problems for the poor, and drought in the west. In very recent years; RDRS has expanded its program to a few more districts in the other part of the country. 18 districts Panchagarh, Rangpur, Dinajpur, Rangpur, Nilphamari, Lalmonirhat, Kurigram, Gaibandha, Jamalpur, Bogra, Naogaon, Chapai Nawabganj, Rajshahi, Natore, Pabna, Sylhet, Moulvibazar and Habiganj. The Central Coordination Office of RDRS Bangladesh is situated in Rangpur, while Head Office in Dhaka. RDRS Bangladesh reaches some over million rural dwellers through its various development interventions. RDRS Bangladesh presently works with $1,572,416$ rural poor of 18 districts in Bangladesh. Its development aim is to achieve sustainable increases in their living standards. With this aim, RDRS Bangladesh enables those who participate in its programme to gain the necessary skills, understanding, confidence, institutions and services; and ensure that the rural communities have the necessary economic, social and environmental resources. In its program, RDRS Bangladesh applies these priorities with a continuing focus on the rural poor, marginalized and disenfranchised, with some engagement with urban slum dwellers in regional towns. We work with two main categories:

- Minorities: excluded and marginalized groups (eg, ultra-poor, indigenous, char/riverine communities, disabled, selected discriminated-against urban poor (slum-dwellers, sweeper community etc).

- Majorities: landless and near-landless/marginal farmers, climate change-affected people, small farmers, health service users.

Particular focus in all categories on Women, Youth (with special focus on adolescents), and children Communitybased organizations of the focus groups (groups, committees, Federations, CBOs, CSOs (including professional fora), Relevant civil society groupings and, indirectly, government at district, regional national and international level. 


\section{Literature Review}

Ahmad (2011) investigates that there is positive relationship between credit and agricultural output. Credit is always helpful for the needy farmers to buy agriculture inputs. Therefore, credit has indirect impact on output because it is important to purchase different agricultural inputs those have strong impact on agricultural output. Ayaz and Hussain (2011) conclude that rural financial markets are improving agriculture sector. Adequate finance for purchasing qualitative agriculture inputs i.e. improved seeds, fertilizer, new technologies and timely utilization of credit also affect the efficiency of farming sector in shape of higher production. Hazarika and Alwang (2003) concluded that improved access to credit by rural farmers can lead to both improved and increased productivity increase agricultural production and income. Saboor et al, (2009) use of modern technology increased demand for credit and resulted in increase in agricultural productivity of small farmers. Siddiqi et al, (2004) reported that flow of credit to farmers had increased demand for inputs to increase crop production. Mohan (2006) examined the overall growth of agriculture and the role of institutional credit. Agreeing that the overall supply of credit to agriculture as a percentage of total disbursal of credit is going down, he argued that this should not be a cause for worry as the share of formal credit as a part of the agricultural GDP is growing. Sriram (2007) concluded that increased supply and administered pricing of credit help in the increase in agricultural productivity and the wellbeing of agriculturists as credit is a sub-component of the total investments made in agriculture. Nosiru (2010) proved in his research article on the topic - Micro credits and Agricultural Productivity in Ogun State, Nigeria \| that micro credit enabled farmers to buy the inputs they needed to increase their agricultural productivity.

\section{Objectives}

[1] To determine the socio-economic factors responsible for the productivity of farmers in the study area.

[2] To investigate into the productivity differentials between the beneficiaries and non-beneficiaries of seasonal loan in the study area.

[3] To find out the constraints of getting credit by the farmers.

[4] To make recommendations on the basis of research findings.

\section{Justification of the Study}

Seasonal loan plays a vital role on changing our farmer's crop production. Seasonal loan brings hope to our farmer's when they become frustrated on their financial condition. Seasonal loan plays just like cool air in hot weather for our small and marginal farmers. NGOs serve the Seasonal loan mostly in the rural area. This study will be conducted in the north eastern region of Bangladesh. The region is very important for our agricultural production and most of the people are related with agriculture. Their economic and social status is not so developed and they mostly depend on credit. A number of NGOs are working in those areas. So it is important to observe the relative change in those areas. The study will help to understand the relationship between Seasonal loan and agricultural crop production. Seasonal loan takes intensive care of our small and marginal farmers. Our country is dominated by small and marginal farmers. The study will show the impact of Seasonal loan on agricultural crop production which is very important for our future course of action. This study will evaluate the Bangladesh activities and their seasonal loan programs.

\section{Methodology of the Study}

\subsection{Selection of Area}

Most of seasonal loan on crop production is provided RDRS Bangladesh at Badarganj upazila in Rangpur districts. So this study covers in Badarganj upazilla of Rangpur districts and I select some areas for collecting data. My study is developed towards the seasonal loan borrower \& non-borrower perspective. I select the areas through non-random sampling method and the respondents are available in those areas.

\subsection{Sampling}

List of borrowers and non-borrowers Rice growers were collected from the RDRS Bangladesh office of the respective upazilla. The sample is selected through simple random sampling method and respondents are selected randomly. Sample size was 55 household where 30 household is seasonal loan borrower \& 25 household is seasonal loan non-borrower.

\subsection{Sources of Data}

The study is involved in collection of data both from the primary and secondary sources. Different types of data and their sources are discussed under the following heads:

\subsubsection{Primary Data}

Primary data were collected by the researcher themselves through personal interview with the respondents. To get accuracy and reliability of data, care and caution were taken in data collection. The researcher's took all possible effort to establish a congenial relationship with the respondents do not feel hesitation or hostile to provide correct data. Prior to interviewing, the objectives of the study were explained to each and every owner of the Tobacco growers. As a result, they were convinced that the study was purely an academic one and was not likely to have an adverse effect on their business. During data collection an attention was also paid to the mood of the owners of the Tobacco growers.

\subsubsection{Secondary Data}

We can't get enough secondary data for this study. The secondary sources include govt. publications; annual reports on Tobacco cultivation, seminar papers, journals, published 
and unpublished thesis, and topic reelected various books, BBS, web site etc.

\subsection{Analytical Technique}

After collecting data, the data should be processed from raw data to final decision through using some analysis technique. The raw data should be arranged systematically. After collecting primary data from the field scrutinized to find out any deficiency or omission in the data collected \& avoid irrelevant information. Qualitative data were collected in quantitative forms by assigning suitable scoring was necessary. Then muster sheets were prepared \& tabular analysis was done. The data gathered were analyzed descriptive statistics like percentages, averages $\&$ frequency count.

\section{Data Analysis \& Result Discussion}

\subsection{Age}

From below table, it can be said that credit borrowers age about $23.33 \%$ range between 16 to 30 years. Again highest $63.33 \%$ borrowers were between 31 to 45 years and $13.33 \%$ were between $46-60$ years. Average age of the credit nonborrower was 35.76 years. Most of the credit borrowers were middle aged and they have started receiving seasonal loan to increasing their Rice production.

Table 1. Age of Respondents.

\begin{tabular}{lllll}
\hline $\begin{array}{l}\text { Variable } \\
\text { Ages } \\
\text { (Year) }\end{array}$ & \multicolumn{2}{l}{ Credit Borrower } & \multicolumn{2}{l}{ Credit Non-Borrower } \\
\cline { 2 - 5 } & Frequency & Percentage & Frequency & Percentage \\
\hline $16-30$ & 7 & 23.33 & 0 & 0 \\
$31-45$ & 19 & 63.33 & 25 & 100 \\
$46-60$ & 4 & 13.33 & 0 & 0 \\
$61-75$ & 0 & 0 & 0 & 0 \\
$>75$ & 0 & 0 & 0 & 0 \\
Total & 30 & 100 & 25 & 100 \\
Average & 37.3 & & 35.76 & \\
\hline
\end{tabular}

\subsection{Gender}

In seasonal loan program of Partner organization about $73.33 \%$ were male where $26.67 \%$ were female credit borrowers in Rice production. But $68 \%$ male \& $32 \%$ female were credit non-borrowers in Rice production.

Table 2. Gender of Respondents.

\begin{tabular}{lllll}
\hline \multirow{2}{*}{$\begin{array}{l}\text { Variable } \\
\text { Gender }\end{array}$} & \multicolumn{2}{l}{ Credit Borrower } & \multicolumn{2}{l}{ Credit Non-Borrower } \\
\cline { 2 - 5 } & Frequency & Percentage & Frequency & Percentage \\
\hline Male & 22 & 73.33 & 17 & 68 \\
Female & 8 & 26.67 & 8 & 32 \\
Total & 30 & 100 & 25 & 100 \\
\hline
\end{tabular}

\subsection{Family Size}

The total people living together are called family size. Average family member of credit borrowers were 5.2 people.
Average family member of non-borrowers were 5.48 people. About $70 \%$ borrowers total family member range from 1 to 4 \& $30 \%$ total family member of borrowers between 5 to 8 people. About 52\% non- borrowers total family member range from 1 to $4 \& 48 \%$ total family member of nonborrower between 5 to 8 people.

Table 3. Family Size of Respondents.

\begin{tabular}{lllll}
\hline Variable & \multicolumn{2}{l}{ Credit Borrower } & \multicolumn{2}{l}{ Credit Non-Borrower } \\
\cline { 2 - 5 } $\begin{array}{l}\text { Family } \\
\text { Member }\end{array}$ & Frequency & Percentage & Frequency & Percentage \\
\hline $1-4$ & 21 & 70 & 13 & 52 \\
$5-8$ & 9 & 30 & 12 & 48 \\
$>9$ & 0 & 0 & 0 & 0 \\
Total & 30 & 100 & 25 & 100 \\
Average & 5.2 & & 5.48 & \\
\hline
\end{tabular}

\subsection{Educational Status}

Education of the respondent was measured by level of class passed. About $16.67 \%$ credit borrowers can sign only, about $16.67 \%$ borrowers study from class 1 to 5 , and about $36.67 \%$ borrowers study from class 6 to 9 , about $6.66 \%$ borrowers completed SSC, about 3.33\% borrowers completed HSC \& about $20 \%$ borrower have passed graduate. But about $32 \%$ credit non-borrowers can sign only, about $28 \%$ non-borrowers study from class 1 to 5 ; about $24 \%$ non-borrowers study from class 6 to 9 , about $12 \%$ nonborrowers completed SSC \& about $4 \%$ borrowers completed HSC. Average educational status of credit borrowers was class 8 passed, but average educational status of credit nonborrowers was class 6 passed.

Table 4. Educational Status of Respondents.

\begin{tabular}{lllll}
\hline Variable & \multicolumn{2}{l}{ Credit Borrower } & \multicolumn{2}{l}{ Credit Non-Borrower } \\
\cline { 2 - 5 } Status & Frequency & Percentage & Frequency & Percentage \\
\hline Illiterate & 0 & 0 & 0 & 0 \\
Can sign only & 5 & 16.67 & 8 & 32 \\
Class 1-5 & 5 & 16.67 & 7 & 28 \\
Class 6-9 & 11 & 36.67 & 6 & 24 \\
SSC & 2 & 6.66 & 3 & 12 \\
HSC & 1 & 3.33 & 1 & 4 \\
$>$ HSC & 6 & 20 & 0 & 0 \\
Total & 30 & 100 & 25 & 100 \\
Average & 8 & & 6 & \\
\hline
\end{tabular}

\subsection{Farm Size}

From below table It can be said that average homestead area of credit borrowers about.187 acre, where credit non borrowers area about.12 acre, average own land of credit borrowers about 2.81 acre, where average own land of credit non-borrowers was 1.43 acre, average land lease from other of borrowers were.76 acre, but credit non-borrowers were. 8 acre. Average total cultivable land of credit borrowers was higher than credit non-borrowers. 
Table 5. Farm Size of Respondents.

\begin{tabular}{lll}
\hline Variable Farm size (acre) & $\begin{array}{l}\text { Credit Borrower } \\
(\mathbf{n = 3 0 )}\end{array}$ & $\begin{array}{l}\text { Credit Non- } \\
\text { Borrower (25) }\end{array}$ \\
\cline { 2 - 3 } & (Average) & (Average) \\
\hline Homestead & .187 & .12 \\
Own land for own cultivation & 2.81 & 1.43 \\
Land from lease & .76 & .8 \\
Total cultivable land & 3.57 & 2.23 \\
\hline
\end{tabular}

\subsection{Credit Received by Borrowers}

Average seasonal loan received by credit borrowers about 22033.33 taka from RDRS Bangladesh. Duration of the credit was 6 month. Average interest rate on seasonal loan was 9.4 percent. Non borrower not received seasonal loan from RDRS Bangladesh.
Table 6. Credit Received by Borrowers.

\begin{tabular}{lll}
\hline \multirow{2}{*}{ Variable Credit } & $\begin{array}{l}\text { Credit Borrower } \\
(\mathbf{n}=\mathbf{3 0})\end{array}$ & $\begin{array}{l}\text { Credit Non- } \\
\text { Borrower (25) }\end{array}$ \\
\cline { 2 - 3 } & (Average) & (Average) \\
\hline Amount (Tk) & 22033.33 & 0 \\
Duration of credit (Month) & 6 & 0 \\
Rate of interest (\%) & 9.4 & 0 \\
\hline
\end{tabular}

\subsection{Practice of Credit Payment Mode}

Below table shows that 100 percent of SL borrowers were engaged in full credit repayment mode for credit repayment to the organization and the average duration for repayment of SL was 6 months. Borrowers were payment the credit to the organization before end of $6^{\text {th }}$ month.

Table 7. Credit Payment Mode.

\begin{tabular}{llllll}
\hline \multirow{2}{*}{ Particulars } & \multirow{2}{*}{ Duration of full Credit payment (month) } & Payment Mode & & \\
\cline { 3 - 5 } & & Full Payment (Percentage) & Weekly (Percentage) & Monthly (Percentage) \\
\hline SL Borrower & 6 & 100 & 0.00 & 0.00 \\
\hline
\end{tabular}

\subsection{Money Source of Non-Borrowers for Rice Production}

From below table It can be said that non -borrowers average used own source about 7000 taka, from family member about 1500 taka, from relative about 1500 taka, from village money lender about 5000 taka \& others credit about 6000 taka for Rice production. Non-borrowers were paid $10 \%$ interest to the money lender \& $12 \%$ interest for the other credit.

Table 8. Money Source of Non-borrowers.

\begin{tabular}{lll}
\hline Source & Amount (Tk) Average & Rate of Interest (\%) \\
\hline Own & 7000 & 0 \\
From family member & 1500 & 0 \\
From relatives & 1500 & 0 \\
Village money lender & 5000 & $10 \%$ \\
Other credit & 6000 & $10 \%$ \\
Total & 21000 & \\
\hline
\end{tabular}

\subsection{Type of Crop Production by Respondent}

Average 1.65 acre land used by credit borrowers for Rice cultivation. It was $46.22 \%$ from total cultivable land of credit borrowers. Where average 1.18 acre land used by credit borrowers for other crops cultivation. It was $53.78 \%$ from total cultivable land of credit borrowers. But average 1.31 acre land used by credit non-borrowers for Rice cultivation. It was $58.74 \%$ from total cultivable land of credit nonborrowers. Where average. 48 acre land used by credit borrowers for other crops cultivation. It was $41.26 \%$ from total cultivable land of credit borrowers. Credit borrower total land size was higher than no-borrower, but use of land for Rice production in case of borrower lower than nonborrower.
Table 9. Type of Crop Production by Respondents.

\begin{tabular}{lllll}
\hline \multirow{2}{*}{$\begin{array}{l}\text { Type of } \\
\text { crop }\end{array}$} & \multicolumn{2}{l}{ Credit Borrower } & \multicolumn{2}{l}{ Non Borrower } \\
\cline { 2 - 5 } & $\begin{array}{l}\text { Average } \\
\text { (acre) }\end{array}$ & $\begin{array}{l}\text { \% of land use } \\
\text { from total }\end{array}$ & $\begin{array}{l}\text { Average } \\
\text { (acre) }\end{array}$ & $\begin{array}{l}\text { \% of Land Use } \\
\text { from Total }\end{array}$ \\
\hline Rice & 1.65 & 46.22 & 1.31 & 58.74 \\
$\begin{array}{l}\text { Other } \\
\text { crop }\end{array}$ & 1.18 & 53.78 & .48 & 41.26 \\
\hline
\end{tabular}

\subsection{Change of Input Use in Rice Production}

From below table, It can be said that average land cost of credit borrowers about 9000 taka, where average land cost of credit non borrowers are 9214.29 tk. Land costs of credit non-borrowers were higher than credit borrowers. Land preparation cost of borrower about 2866.67 taka, but nonborrower cost about $2528 \mathrm{tk}$. Average own labor cost 2427.59 taka where hire labor cost 3113.33taka of credit borrower, but own labor cost 2928 taka \& hire labor 2620 of credit non borrower. Own labor cost was lower than higher hire labor cost in case of credit borrower, but hire labor cost was lower than own labor cost for non-borrower. Average seed cost of credit borrowers 676 taka \& non-borrower seed cost 663.2 taka later one was lower than former one.

Average fertilizer cost of borrower was 6069.33 taka, but non-borrower cost about 5846.4 tk. Borrower's fertilizer cost was higher than non-borrower fertilizer cost. Average vitamin cost of borrower was 411.33 taka, but non-borrower cost about 396 tk. Borrower's vitamin cost was higher than nonborrower vitamin cost. Average pesticide cost of borrower was 950 taka, but non-borrower cost about 848.8 tk. Borrower's pesticide cost was higher than non-borrower pesticide cost. Average herbicide cost of borrower was 286 taka, but non-borrower cost about 248.8 tk. Borrower's herbicide cost was higher than non-borrower herbicide cost. Average insecticide cost of borrower was 527.33 taka, but non-borrower cost about 526.4 tk. Borrower's insecticide 
cost was higher than non-borrower insecticide cost. Both borrower \& non-borrower not used pheromone trap \& porous pipe. Average irrigation cost of borrower was 5093.33 taka, but non-borrower cost about 5312 tk. Borrower's irrigation cost was lower than non-borrower fertilizer cost.

Table 10. Change in Input Use of Respondents.

\begin{tabular}{lll}
\hline $\begin{array}{l}\text { Input used in Crop } \\
\text { Production (acre) }\end{array}$ & $\begin{array}{l}\text { Credit Borrower } \\
\text { Average (tk) }\end{array}$ & $\begin{array}{l}\text { Credit Non-Borrower } \\
\text { Average (tk) }\end{array}$ \\
\hline Land cost & 9000 & 9214.29 \\
Land preparation cost & 2866.67 & 2528 \\
Own Labor cost & 2427.59 & 2928 \\
Hire labor cost & 3113.33 & 2620 \\
Seed cost & 676 & 663.2 \\
Fertilizer cost & 6069.33 & 5846.4 \\
Vitamin cost & 411.33 & 396 \\
Pesticides & 950 & 848.8 \\
Herbicide & 286 & 248.8 \\
Insecticide & 527.33 & 526.4 \\
Pheromone trap & 0 & 0 \\
Porous pipe & 0 & 0 \\
Irrigation & 5093.33 & 5312 \\
Equipments & 52.33 & 50.4 \\
Harvesting & 4586.67 & 4768 \\
Others & 1766.67 & 1560 \\
Total Input Cost & 31445.67 & 33456 \\
Overhead cost & 3144.57 & 3345.6 \\
Total cost & 34590.24 & 36801.6 \\
\hline
\end{tabular}

Average equipment's cost of borrower was 52.33 taka, but non-borrower cost about 50.4 tk. Borrower's equipment's cost was higher than non-borrower equipment cost. Average harvesting cost of borrower was 4586.67 taka, but nonborrower cost about 4768 tk. Borrower's harvesting cost was lower than non-borrower harvesting cost. Average others cost of borrower was 1766.67 taka, but non-borrower cost about 1560 tk. Borrower's others cost was higher than nonborrower others cost. Average total input cost of borrower was 31445.67 taka, but non-borrower cost about 33456 tk. Borrower's total input cost was lower than non-borrower total input cost. Average overhead cost of borrower was 3144.57 taka, but non-borrower cost about 3345.6 tk. Borrower's overhead cost was lower than non-borrower overhead cost. Average total cost of borrower was 34590.24 taka, but non-borrower cost about 36801.6 tk. Borrower's total cost was lower than non-borrower total cost.

\subsection{Change in Production Unit}

Average Rice production of seasonal loan borrowers per acre were 2.89 M.ton. Average Rice production of seasonal loan non-borrowers per acre were 2.86 M.ton. Rice production of credit borrowers was higher than credit non-borrower.

Average per unit price of Rice was 13925 taka in case of borrower. Average per unit price of Rice was 14530 taka in case of non- borrower. Per unit price of Rice for credit borrowers lower than credit non-borrowers. Average total value of Rice in case of borrowers was 40243.25 taka, but average total value of Rice for non-borrower was 41555.8 taka. Non-borrower average total value of Rice was higher than borrower. Average total value of straw both were same. That was 3600 taka.

Table 11. Change in Production Unit.

\begin{tabular}{lllllll}
\hline & Total amount (M.ton/acre) & Price (Tk/unit) & Total Value (Tk) & Total Amount (M.ton/acre) & Price (Tk/unit) & Total Value (Tk) \\
\hline Rice & 2.89 & 13925 & 40243.25 & 2.86 & 14530 & 41555.8 \\
Straw & & 3600 & & & 3600 \\
\hline
\end{tabular}

\subsection{Profitability}

This section deals with profitability in Rice production financed by the households receiving SL and without SL. Below table shows, in Rice production per acre of land by the households who receive SL was 2.89M.ton. That was average total value about 40243.25 taka. Average total straw value was 3600 taka. Gross return was 43843.25 taka of produced per acre of land. Total cost per acre land was 34590.24 taka. Net return of SL borrower per acre Rice field was 9253.01 taka.

Below table shows, in Rice production per acre of land by the households who not receive SL was $2.86 \mathrm{M}$.ton. That average total value was 41555.8 taka. Average total straw value was 3600 taka. Gross return was 45155.8 taka of produced per acre of land. Total cost per acre land was 36801.6 taka. Net return of SL non- borrower per acre Rice field was 8354.2 taka.

Table 12. Profitability of Rice.

\begin{tabular}{lll}
\hline \multirow{2}{*}{ Variable } & Credit Borrower (Average) & $\begin{array}{l}\text { Non Borrower } \\
\text { (Average) }\end{array}$ \\
\cline { 2 - 3 } & Total value (Tk) & Total value (Tk) \\
\hline Rice & 40243.25 & 41555.8 \\
Straw & 3600 & 3600 \\
Gross Return & 43843.25 & 45155.8 \\
Total Cost & 34590.24 & 36801.6 \\
Net Return & 9253.01 & 8354.2 \\
\hline
\end{tabular}

\section{Constraints Face by Credit Borrowers}

[1] The amount of credit is not satisfying the requirement of seasonal loan borrower. Now production cost is higher, so they expect more credit. 
[2] Time duration of credit repayment is six month only that is not sufficient to the borrower. Because in this time period they cannot sale their product with high price.

[3] The cost of borrowing in SL still has element like (nonrefundable) welfare (or insurance)

[4] Fund and undue interest is charged on amount paid up.

[5] Many farmer face sudden hazard due to natural calamities, but they not receive any support from organization.

[6] All credit borrowers are not receiving proper training, seed, fertilizer, \& technological support from organization.

\section{Difficulties Faced in Collecting Data}

The borrower had no idea about such study, they were highly apprehensive about purpose of the study. The initially hesitated to answer the questions and show unfriendly attitudes. They thought that this survey killing their valuable time. But when the understood that it was academic, then they become convinced \& agree to co-operate. Another problem of respondents was busy in their work, so collect data had to go the borrower as their convenient times. Besides, the data/information is not tested, because they have no record or $\mathrm{A} / \mathrm{C} \&$ book keeping. So it was difficult to collect accurate data.

\section{Limitation of the Study}

[1] Sample size is small. Time duration for collecting the data from respondents is short. For that reason sample size are small.

[2] Due to deficiency of time the study could not cover wide side areas for gathering obligatory information.

[3] Some written records were asserted by the literate respondents, but maximum respondents had no written document. Therefore, the researcher had to depend solely on the memory of the respondents.

[4] The largest part of the farmers in the study area contemplation that the investigator was a government officer. So, they originally hesitated to answer the questions relating to their income and expenditure. Some were afraid of imposition of new taxes.

\section{Conclusion \& Recommendation}

Above discussion of the result some finding was observed. Average ages of the credit borrowers were higher than non-credit borrower. Male respondent of credit borrowers \& non-borrower were higher than female respondent. Family sizes of SL borrowers were lower than SL non-borrower. Respondent of SL borrowers were more conscious about family planning than non-borrowers. Educational status of borrowers were high, But nonborrowers status were low. The borrowers were more educated they apply knowledge in Rice production effectively. Homestead area \& own lands for crop cultivation of borrowers were larger than non-borrower, but land lease from other for crop production of borrowers were smaller than non-borrowers. Social statuses of SL borrowers were high. Percentages of land from total land were used for Rice production by SL borrowers lower than non-borrowers. SL borrowers used more land for other crop cultivation such as maize, wheat \& other vegetable. Because this type of crop more profitable than Rice. Besides non-borrower use more land for Rice production, because they were not met production cost of other crops. The money received by non-borrower from local money lender \& other credit provider for Rice production rate of interest was higher than seasonal loan's interest rate that was received by SL borrower. Non-borrower amount was lower than borrower amount for Rice production. Production costs of SL borrowers were lower than SL nonborrowers. Though Land preparation cost, Labor cost, Seed cost, Fertilizer cost, Vitamin cost, Pesticides cost, Herbicide cost, Insecticide cost, Equipments cost \& other cost in Rice production of SL borrowers were higher than SL nonborrower, but Land cost, Irrigation cost \& Harvesting cost were lower than non-borrower. SL non-borrower cultivated land by lease for that reason land cost higher, Land far away from home as result harvesting cost higher, they were not financially strong lease the water from rich one \& pump machine far away from land so irrigation cost were high. The loan received by SL borrower its amount were very small if we compared with their total production cost, total cultivable land \& market price of input. Average Rice production of SL borrowers were higher than non-borrower, but unit price of Rice received by borrower was lower than non-borrower, because borrower quickly sell the Rice in the market for repayment the loan to the organization.

Therefore, in order to enhance the productivity of the beneficiaries of the seasonal loans, the following could be suggested:

[1] The amount of credit is very small considering their farm size. So it should be increased.

[2] Time duration of credit repayment should be increased up to 9 months as PKSF rules.

[3] Some processing fee is charged. This should be stopped.

[4] Other Technical guidance related to productivity may be provided to the farmers by the organization through training, workshops \& input supply.

[5] Financial subsidies should be provided in purchasing of quality inputs (i.e. seeds, fertilizers, pesticides and others).

[6] Most of the borrower expects modern technological support. It should be provided to the borrowers.

[7] To provide support (disaster loan, crop insurance \& rescheduling etc) to the borrower when any sudden natural hazard occurred.

[8] In harvesting season the supply of Rice is much higher than the other times. So, it is natural that the price of Rice in harvesting season will be decreased. Ways 
should be find out to maintain reasonable price in all time (may be Rice is to be stored).

\section{References}

[1] Hossain, M. M. 1986. Credit needs of Rice farmers-An analysis of farm level data. Bangladesh J Agril Econ 8 (1), 116

[2] Jaim W. M. H and Rahman, M. L. 1985. Cash Flow of Rural Household: A Micro Level Study in Bangladesh. JAgril Econ 8 (2).

[3] Ahmad, Nawaz (2011). Impact of Institutional credit on agricultural output: a case study of Pakistan. Theoretical and Applied Economics. Vol. XVIII, No 10 (563). pp. 99-120.

[4] Ayaz, Saima \& Hussain, Zakir (2011). Impact of institutional credit on production efficiency of farming sector: A case study of District Faisalabad. Pakistan Economics and Social Review, Vol. 49, No. 2, pp. 149-162.

[5] Hazarika, G. and Awang, 1. 2003. Access to credit, plot size and cost inefficiency among smallholder tobacco cultivators in Malawi. Agricultural Economics, 29: 99-109.

[6] Saboor Abdul, Maqsood Hussain and Madiha Munir (2009), - Impact of micro credit in alleviating poverty: An
Insight from rural Rawalpindi, Pakistan,\| Pak. j. life soc. SLi. (2009), 7 (1): Pp90-97.

[7] Siddiqi Muhammad Wasif Mazhar-ul-Haq, Kishwar Naheed Baluch (2004), - Institutional credit: A policy tool for enhancement of agricultural income of Pakistan.\| International Research Journal of Arts \& Humanities (IRJAH) Vol. 37.

[8] Mohan, Rakesh (2006): 'Agricultural Credit in India - Status, Issues and Future Agenda', Economic and Political Weekly, 41: 1013-1021.

[9] Sriram M. S. (2007): 'Productivity of Rural Credit: A Review of Issues and Some Recent Literature', Indian Institute of Management Ahmedabad, Working Paper No.2007-06-01.

[10] Nosiru, Marcus Omobolanle (2010), Micro credits and agricultural productivity in Ogun State, Nigeria. World Journal of Agricultural sciences 6 (3): Pp290-296, 1817-3047 (C) IDOSI Publications.

[11] Bangladesh Bureau of Statistics (BBS) (modified 2014, May 28). http://www.bbs.gov.bd.

[12] Rangpur Dinajpur Rural Service (RDRS Bangladesh), (modified 2014, June 11). http://www. RDRS Bangladesh @bangla.net.

[13] Agriculture in Bangladesh (modified 2014, April 27). In Wikipedia, the free encyclopedia. Retrieved May 1, 2014, from http://en.wikipedia.org/wiki/Agriculture_in_Bangladesh. 